\title{
ASSESSING THE DEVELOPMENT AND FUTURE OF MORAL-BASED ACTIONS AND LEADERSHIP IN SCIENCE AND TECHNOLOGY SECTORS IN INDONESIA
}

\author{
Christian Gerald Daniel \\ Pelita Harapan University \\ christian.daniel@uph.edu
}

\begin{abstract}
A solid understanding of ethics is one of the most crucial aspect in any technological or scientific progress. Any development proceeded without proper knowledge of ethical value will drive the process to fall under the risk of failure that often damages the surroundings. In this paper, numerous essential ethical theories from various philosophersare elucidated herein to yield a general code of conduct as the basis to analyse several cases in several sectors, such as academic, engineering and medical, in attempt to locate any potential violation of values in accordance to the aforementioned study. Furthermore, several key points regarding the suggested moral virtues are summarised from the ethical code in the respective sectors to gain an understanding of the application of the theorems to the conducts. Lastly, numerous attempts of improvement in each sector; one example is the broader opportunity of conducting research supported by the government, are discussed in the last segment of this paper. The ultimate goal is then to illustrate the development of effort made in each sector in Indonesia learn from the mistakes to improve the condition with respect to the moral virtues and sustainability.
\end{abstract}

Keywords: ethics, development, academic, construction, medical, sustainability

\section{INTRODUCTION}

Ethics and moral are the questions that will always exist in any scientific development. In fact, any development should be able to pass certain ethical questions, such as the intention behind the discovery, the side effects to the society or environment, etc. with positive outcomes in order to avoid being used for a wrong purpose. However, the abuse of the development, which surely does not comply to the norms and ethics, has often occurred and disturbed not only the advancement of science and technology, but also the environment and society. Several notable tragedies in the history have given the proof of how dangerous that could be. There have been numerous occasions in which the responsible parties did not seem to act with regards to the norm or moral virtue, and even violated the ethical code of their profession while developing a project. There are several cases in the past in Indonesia, such as the tragedy of mudflow in Sidoarjo, the split earth in Surabaya, and several cases in academia environments, which reflect the failure of the involved stakeholders to assume their roles according to the respective moral virtues, resulting in a lethal consequence not only to them, but also to the neighbourhood; those cases are documented in this paper. However, one cannot simply pass a judgement regarding the violation of ethics and norms without having a full consideration regarding the instance. Therefore, it can be difficult at times to justify an act to comply to the ethical codes and norms, and ultimately, to live the virtues while making decisions as the leader in the fast-paced industries nowadays. This paper then attempts to present the basic insights of ethical norms and virtues necessary to elaborate the presented 
case studies, then conveys several instigations of improvement in related science and technological sectors in Indonesia to describe the opportunities for the involved parties.

\section{LEADERSHIP, ETHICAL, AND SUSTAINABILITY ASPECT IN SCIENCE AND TECHNOLOGY}

The word science was derived from Classical French, whose origin is the Latin term "Scientia", translated as knowledge, expertise, or experience(1). Another root word for science is episteme, brought up by Aristotle, which basically means knowledge. Based on the etymology, science is defined as the pursuit and application of knowledge, which could cover every aspect of knowledge possible, and understanding of the natural and social world following a systematic methodology based on evidence(2). Moreover, Van Niel stated that science is essentially a perpetual endeavour for an intelligent and integrated comprehension of the world (3). Evidently, the true value of science is not just simply implemented by telling a fact, but beyond that, there lies a responsibility to explain the truth behind such fact by using sets of arguments and data to understand the true meaning behind a phenomenon. Based on the definition, any scientific methodology must include several processes, starting from an observation and/or experiment technique that must be repetitive, then whose outcome comes in the form of hypothesis that must be analysed and tested objectively to yield a verifiable and sound result in the end, or to confirm the hypothesis. However, there are also different opinions regarding the definition of science, which indicates the potential of bias in science, in contrast to the neutral image implied from previous descriptions. A quote from Dyson could sum up the premise perfectly, as "all of science is uncertain and subject to revision. The glory of science is to imagine more than we can prove."(4). Moreover, Oxford English Dictionary gives a definition of science as the intellectual and practical activity that systematically attempt to study the structure and behaviour of any natural and physical phenomena by means of observation and experimental approach. The given definition obviously appears to give a recognition to the actor behind such "activity", which is obviously a human consisted of flesh and blood with certain interests and bias thoughts, which can freely decide to perform any action towards his/her endeavour to achieve the end goal. Therefore, any actions performed by the actor should be subjected to the moral and ethical values examination(5). Meanwhile, technology can be viewed as the practical application of scientific knowledge, as suggested by Compact Oxford English Dictionary. This could also mean that both technology and science need to be controlled by a set of moral, or virtue, to avoid any conflict rising from the abusive behaviour in the application of a scientific knowledge or technology as opposed to its initial motive behind such discovery, or to prevent any negative design behind a creation of scientific knowledge or technical innovation.

The word ethics itself is a derivative of the Greek term ethica, meaning custom, moral, or conviction. While ethics and moral are basically equivalent, the term moral is often denoted as the basis of any positive conduct or behaviour.

The study of ethics draws to the process of developing both descriptive judgements, which is based on the real occurrences in the past, present and future to generate a true or false answer based on a rather direct ethical value - acceptable or unacceptable, etc. (for instance, whether the standard protocol for the medical personnel has met the safety regulations or not); and normative judgements, which is based on an idea of ideal condition, or whether things should be considered good or bad, etc. (for example, if it is good to enforce the death sentence or not). The judgment based on certain ethical values will lead to a norm, which basically entails a set of specific value that is a result of consensual agreement of several parties to judge a concrete action according its suitability to the norm. The norms can then transform into a rule or regulation that bind a certain society, which will become the ground to set a moral virtue of a person subjected to the regulation. There are at least three different categories of ethical theory fabricated from the definition, namely utilitarianism, duty ethics, and virtue ethics. The first theory highlights the importance of judging any action 
solely by measuring its output. One of the most well-known tools for the measurement is the usefulness of the end result, whose method is famously called utilitarianism, a term popularised by Jeremy Bentham in the $18^{\text {th }}$ century. A famous definition by him, "the principle of utility is meant that principle which proves or disapproves of every action whatsoever, according to the tendency it appears to have to augment or diminish the happiness of the party whose interest is in question." (6). Meanwhile, duty ethics (or deontological), which was heavily influenced by the theory of Kant (1785), identifies a good deed according to its suitability to the governing regulation/norm. The basic idea behind the theory is that there is a sense of duty based on good will to place norm/value, instead of personal happiness, on top of each notion. A good application of the thought is in form of hypothetical norm, which basically identifies an obligation to perform a positive action to achieve a positive goal, or vice versa. Lastly, among the other theories, virtue ethics is the one that was developed firstly among the ancient Greek philosophers, namely Aristotle, Socrates, and Plato. This theory clearly shifts the attention from the behaviour to the actor behind the gun, which basically means that a person should strive to become the best version of himself to become full and enjoyable. Further explanation of this theorem aspires anyone to pursue the practical wisdom in every situation, achieved by extrapolating the positive and negative extremes based on certain intellect. The equilibrium concept herein is a relatively dynamic concept, reciprocating the given circumstances. Therefore, one needs to perceive the situation carefully prior to giving the correct response, a skill arisen from his inner virtue. For example, the best choice for a good doctor whether to express the blunt, honest diagnose of the patient, or to give them hope to endure during difficult treatments (7). In reality, all of the theorems can only do so much separately since there are several weak points in each of them. For instance, the concept of personal happiness as the end goal in utilitarianism is relatively abstract that creates a potential danger of unending pursue of it, which will eventually drive to abuse or exploitation. As for duty and virtue ethics, there lies a substantial doubt regarding the ultimate righteousness in the act and in the actor, and whether both are based on an abstract concept. For instance, an engineer can face a dilemma in developing a project plan, whether to prioritize safety or economical value in the design, where there can be no apparent middle course as the best possible solution, and thus, a hard choice must be selected. Conclusively, there should be a good combination between the three concepts to create the most prominent boundary and ethical conduct to every occupation in scientific and technological field. Another similar theory has been instituted by Confucius, both relying on the willingness to do the good thing. The difference between both concepts lies in how Confucius deliberately paid a significant attention to nationalism, or blood relationship, and seek the ethics as a path to understanding the Heavenly Way, in contrast to the virtue of Aristotle and Kant that focus on universal situation (8). Nonetheless, both the "western" and "eastern" approaches must be applied appropriately, which then will reveal the practical discussion of the responsibility for any professional in scientific and technological fields, which can be classified into the passive and active responsibility (9).Passive responsibility can be described as a "backward-looking responsibility", which is relevant after something undesirable occurred. In the following type of responsibility, a professional must be able to hold account against any actions taken within his/her expertise. In addition, the very same person must always be ready to become target of any blame that rises in sequence to his/her action, or judgement. Nonetheless, the judgement for a certain blameworthiness must be in accordance to several principles, instead of automatically applying the diagnosis. The first quest is to find whether the action has violated any norm, which can be viewed as two different frameworks, namely the moral virtue and professional conduct. Secondly, is whether the alleged party has a causal contribution to the undesirable consequence or situation. The causal contribution indicates both a wrong action and a decision not to act. Thirdly, whether a terrible situation is completely unforeseeable, or the intended party should have been able to forecast using the respective expertise. Lastly, one 
needs to check should an action be based on a full degree of freedom, or if the prosecuted party had been under any kinds of coercion. Passive responsibility, while being widely used until 1990s, often fell under criticism for its excessive fixation to finding an entity to be blamed, which often turns out to be a collective error instead of single mistake, known as the problem of many hands (10); instead of striving to generate a solution(11)(12)(13)(14). Active responsibility then emerges from the critiques, which aims to shape a forward-looking, active type of responsibility to prevent or avoid any foreseeable consequences, or to obtain a valuable end result(15). This formulation holds a paramount concern to having an enthusiasm to explore new possibilities and tackle any challenges with regards to the necessary wisdom based on the moral virtues to avoid any unwanted side effects from the scientific or technical invention. Such significant drive is regarded by Samuel Floorman as "the existential pleasures of engineering". Naturally, any effort to do scientific or technical progress needs to employ both efficiency and effectiveness. Ultimately, the development should be directed towards "the enhancement of human welfare" (16). All the covered aspects are critical in defining the pathway of scientific and technological developments, and even more crucial for the person assuming the leadership positions. As a leader, one must bear the responsibility to marshal the team members through collaborative spirit to achieve the mutual goal and doing so constantly. A good leader, according to Ross Perot, must seek to lead by inspiring and giving influence, not by trying to manage and manipulate people(17). There are numerous books and writings trying to establish the traits of a good leader, among them are self-confident, visionary, able to communicate, holds integrity, honesty and transparency, inspiring, possess a good commitment and humility, able to learn from past failures, able to empower the team members to innovate and become the better version, and must be prepared to bear responsibility of any effect of the actions taken by the organisation(18)(19)(20). Moreover, a study by Pew Research Centre has been able to group the most critical values of leadership by conveying a survey, ranging from the most to the least important in following order: honest, intelligent, decisive, organized, compassionate, innovative, and ambitious. Finally, a report by Cambridge summarised several capabilities of global-scale leadership, namely able to think systematically, open-minded, inclusive, navigate the complexity, have a long-term vision, globally conscious, and able to do interdisciplinary projects(21). All the traits and values must be possessed particularly by the stakeholders in any field of science and technology, who play a prominent role in defining the future of the society altogether, ultimately by the person who holds the leadership position within the stakeholders, to shape the better future for the society.

\section{LEARNING FROM THE PAST - SEVERAL CASE STUDIES IN INDONESIA}

Indonesia has been well-known as one of the religious countries whose constitutions truly embody both the religious and moral values, as it can be seen in Pancasila and the Basic Constitution (UUD 1945). Moreover, the whole concept of Pancasila provides a morale ground in each aspect of living in society. However, it is also not uncommon to see the news regarding immoral conduct and behaviour all over the nation. One glaring instance is corruption, which has quite rooted mentally and become a major issue in our society, from top to bottom. Various cases of corruption can be seen in the news, from the corruption of the lawmaker(22) to the simple case in the neighbourhood(23). The similar issue might also exist in the scientific realm in Indonesia, with clear examples shown in the form of plagiarism and cheating. Plagiarism and cheating have been heavily recited within our scientific culture, which obviously inhibits the ability to maximise the development. One of the most notable cases is about one of a $\mathrm{PhD}$ student who spread false information about his scientific profile and achievements for any unclear purpose(24)(25), which can be considered as cheating that is lack of ethical value. Another sad example is the national bibliometric ranking (SINTA) organised by the Ministry of Research and Technology / National Agency for Research and Innovation (Kemristek/BRIN) to value the scientific works performed by the scientists and research communities, whose application opens the window to attempt ethical manipulations 
in terms of the inflation of self-citations as well as the low-quality works produced without a good-quality review system. Such efforts have even been spotted by Kemristek, where the ministry issued an announcement in 2018 to blacklist the account of several researchers due to the unethical approach(26). In addition, a tendency of nepotism has risen among the community of researchers in the form of the authorship inclusion in a publication work without any clear contribution just in order to increase the recognition of respective authors in the ranking system (27). All of those efforts stem from the main goals, which are merely to increase the productivity and gain the incentive (28). In addition to the fundamental problem in the research realm in Indonesia regarding the low productivity of research and publication, that can be linked to both external factor regarding the finite amount of resources provided by the government and the private entities compared to other countries (research activities only accounted approximately $0.24 \%$ of the country's GDP in 2017)(29)(30)(31)(32) and the lack of quality (also quantity) of the works of local researchers as the chief internal factor (33)(34)(35), the issue with moral and ethics need to be quickly resolved within the research community to be able gain more public trust and shape a better future.

Not only regarding academic publication and journals environment, the act based on questionable ethics and morale background can also occur in other industries, such as construction, that sometimes lead to a dangerous situation. One extreme example is the case of Gubeng street in Surabaya in 2018, where a sinkhole appeared and swallowed the entire road structure, thus disconnecting the road network and yielded a significant loss for the structural reparation as well as the potential economic loss due to the isolation which lasted for ten days. This event occurred due to a technical blunder made in the construction of basement at a hospital adjacent to it, which did not establish a retaining wall to sufficiently reinforce the soil structure in the location(36)(37). The drama ended almost a year later with the punishment given to several persons, namely the site engineer and project manager(38).

The stakeholders of the project can be viewed to violate the moral virtue as the engineers, or the technical representative of the project, are supposed to be able to lead the team to act based on a sound, and accurate judgement, as well as to bear the responsibility should an accident occur within his/her task. In addition, the moral obligation of the technical party in the local government could also be questioned, whether the preliminary examination of the construction project had been perfectly executed, that perhaps, such accident could have been avoided (39). Lots of other accidents have also occurred in the past which brought worse effects regarding the fatalities or significant monetary loss, one of the most notable as well as controversial projects being the mudflow case in Sidoarjo back in 2006, where mud suddenly flew over the mining site in Sidoarjo, causing a vast amount of area being wholly drowned in the mud, not only causing social problems regarding the people who lost their land, but also health and environmental hazard until today (40). Such tragedy had long been alleged due to the error in the project operation, albeit still being unclear until the present day(41). There are numerous researches documented that support such suspicion, with the majority of them pointed out the error in the drilling procedure as the triggering factor of the mud eruption (42)(43)(44)(45). Should the allegation of human error be indeed the real cause, then all the parties are held accountable, least of it the moral account, on this case. This case did not only involve the engineering entity (and leader) who executed the project that should have been aware of the potential and thus enacted the correct procedure as part of their primary virtue to ensure the safety and welfare of the public; but also the other parties, whose technical expertise are considered as competent, who should have been responsible forinvestigating this tragedy but yielded a highly debatable judgement until now. Regardless, both the government and the engineering party have issued a substantial amount of fund during these years to mitigate the so-called disaster and pay the loss of the people situated in and nearby the $\operatorname{area}(46)(47)$. 
There are also numerous other cases which seem to be not so much critical or essential. Nevertheless, there are still violations of ethical conduct that have been done in such practices. For instance, a research byHermawan(48) covers several cases of the cartel in the pharmaceutical industry, starting from manipulating the ingredient of a drug, giving a deceptive description of the product, as well as the monopoly in the distribution of the medicine through the cooperation between the distributor and hospital or doctor; the latter case was also explained by the research ofPujiastoeti et al. (49), stating that there could be an indication of a relationship between such practice and the considerable rise of the price of medicines. Moreover, there was even news covering about a state pharmaceutical company which was suspected to mismanaged their stockpile of medicine that caused the loss of almost IDR 100 million in 2019 (50).

Even in 2020, when trying to analyse the pandemic situation, there are several occasions that can be subjected to the ethical examination. For example, the decision of the state to not ensuing the total lockdown should also be evaluated from the perspective of ethics and moral, whether such decision, backed up by the economic judgement regarding the potential of giant economic crisis mainly due to the rise of the number of unemployment, has covered each aspect of the ethical point of view optimally. Among the perspectives are if there is any dangerous side effect that should have been taken into consideration, or whether the full benefits could outweigh the loss, i.e. if the potential death toll is worth the expected positive outcome (51). Moreover, there has also been a complaint on the transparency of information transmitted from the stakeholders to public. The critic covers how the obligation of social distancing and wearing mask is not entirely well-spread to the society to the clarity of the government's response and decision during the circumstances(52).

\section{ETHICAL CONDUCTS IN SEVERAL INDUSTRIES IN INDONESIA AND CURRENT ACTIONS OF IMPROVEMENTS}

All of the aforementioned cases have shown how terrible the conditions could have become as the result of unethical behaviour, as well as how the implementation the ethical values and moral virtues in the field of science and technology should become a paramount concern, since both of them possess important roles in driving and guiding the development for either the better of worse wellbeing of the society. Therefore, the knowledge basis of ethical and moral virtues must be further established, or least of it included, in the development of the law, both of national and regional scope. Thankfully, such aspiration has been realised and approved by the regulator, which can be seen from the whole laws that organise ethical conducts of each profession. The regulation issued by the Head of Indonesian Institute of Science (LIPI) has declared the desired virtue of the researcher in Indonesia, such as integrity, honesty, and justice. Furthermore, there are four responsibilities of a good researcher described in the book, namely to develop a research product which complies to the standard, supports as the basis of human welfare, gets recognised as an agent of development, and contributes to the development of the organisation. Last but not least, the regulation clearly indicates numerous kinds of possible improper behaviour by any scientist/ researcher, such as dishonesty in the form of data falsification and self-fabrication, as well as any act of exploitation and plagiarism, or cheating, of any kind. This could mean that any technological advancements done by a researcher must be carefully tailored not to violate the code, by also using the required means properly and responsibly. Any kinds of violation will be subjected to the examination of an independent ethical committee to ensure the objectivity of any related judgement (PeraturanKepala LIPI 2007). Every points included in the conduct share a common goal, which is to set any scientific communities in the right position to optimally pursue and lead the realisation of any kinds of scientific development and innovation, in order to enhance human welfare and civilisation, as a part of sustainable development initiative(53).

For instance, the regulation from Ministry of Public Works and Housing of Indonesia (54) has clearly stated the key points of the required moral virtue of the actors involved in this 
affair, namely visionary, integrity, professionalism, responsibility, and service. The actors are supposed bear a moral responsibility to lead the development in their respective roles with integrity and professionalism to serve the needs of the society and develop the country. The implementation of such vision in the leadership situation includes the ability to show a strong commitment to accurately plan and execute any strategic technological development with respect to the rule and attention to other aspects such as economic, social and cultural norms. Additionally, the person of interest should be able to show his integrity while being the integral part of the advancement, such as to be able to maintain the trust and also the courage to bear responsibility as well as to blow the whistle upon any violation against the law. Lastly, the collaborative spirit is also incorporated inside the regulation, highlighting the importance of the factor to achieve the improvement in respective field. Moreover, the national constitution about construction services (UU Jasa Konstruksi 2/2017), from which the Ministerial Regulation (Permen PUPR 7/2017) rooted, has generally indicated the same desired virtues with an extra key point as the main goal: sustainable development(55). Not only that, the key aspects of the regulations have also been adopted into the ethical conduct of many of the professional institutions, each with their own point of views.

Judging from the given case studies, it can be seen that all the stakeholders who contribute to the development in Indonesia, particularly in scientific and technological fields, have created a significant effort to improve the conscience and moral virtues of the practitioner in their respective fields to avoid doing the mistakes in the past, as well as to set the better ground for future generation. This coincides with the very definition of sustainable development itself regarding the development performed to meet today's demand without sacrificing the needs of the future generation. Obviously, a good moral ground is necessary to be able to shape the development while considering every interest, not only the regarding the technology or science itself, but also the social, economic, and even environmental aspects.

Furthermore, a better commitment towards the implementation of norms, particularly ones that are embodied by Pancasila, have been shown in various scopes of developments. Ultimately in scientific and technological fields, several regulations that have been discussed previously have illustrated the initiative of the state to support the sustainable and ethical development in respective sectors.

In academic sector, there are currently several breakthroughs developed by the Ministry of Education and Culture aiming specifically to upscale the quality of education and research activities. The list of the efforts includes the ever-increasing research grants, ranging from the grant for the research by graduate students, fresh lecturer and researcher to the grant for the joint research between universities and world class research, on both theoretical and applied science and technology fields(56). The total fund provided by the state budget is estimated around IDR 42.166 trillion, with an increase of approximately IDR 6.5 trillion from the budget in 2019(57)(58).Moreover, there has been a positive collaboration between several ministries to form a scholarship funding entity, named Indonesian Endowment Fund for Education (LPDP) that offers opportunity for the young generations (those below 40 years old) to tailor their study furthermore to the best universities in Indonesia and world wide, fully funded by the government. The main target of the programme is to prepare more future leaders and professionals through a better education as well as to empower the innovation on entire sectors (59). Additionally, the role of the private entities must also be taken into consideration, which in this case are exemplified by various scholarship programmes opened by various companies to the college students (60)(61)(62) and joint research projects between the industry and research companies, contributing around $10 \%$ of the total R\&D development until now according to the Minister of Research and Technology / National Research and Innovation Agency(63). Another good example an action done by a private company to initiate a funding source for research projects specifically in food technology field, in collaboration with several universities (64). Needless to say, there is a room for improvement 
in each aspect for the better future(65). All of these have been done as part of the ultimate goal of Indonesia in 2045 to raise the golden generation that excels in each sector, driven actively by the research and development in science and technology aspects, as carefully elucidated in the national research and strategic plan(66). The initiatives are also performed to create the professionals who is capable in contributing to research and academic field based on a higher integrity to incorporate the working methods that will not subject to ethical infringement. However, all the stakeholders still have to collaborate to complete the task of raising the total budget for research in Indonesia, which is currently estimated at only $0.25 \%$, from the ideal ratio of $1 \%$, from the total GDP(67). Interestingly, the report shows a gradually increasing interest of the youth in research activities(68), though there are still many more personnel and works are needed in this field of industry. Thus, the synergy between the government, professional industries, and the research entities is still in need of further development(69).

Last but not least, there might even be a higher window of opportunity to do research and innovation throughout the pandemic situation in 2020, where the whole nations are struggling to find the cure of the disease. This can be seen by the new special grants, available both through the initiative of the government through the related ministry and through the synergy between the government of Indonesia and England (namely the Newton Fund Institutional Links - KLN programme), to the research related to Covid-19, by means of which there have been more than 20 ongoing researches funded by the grant $(70)(71)$. The current state obviously put the researchers, particularly related in the mitigation of the pandemic sectors, in a strategic position to become the impactful leaders with strategic roles to overcome the bad circumstances. The strategic position of the healthcare practitioners and researchers must also surely be well regulated to fulfil the required moral obligations and virtues. Otherwise, there could be a lot of potential of abuse using the power. Therefore, strict ethical conducts has been developed and improved constantly based on the international ethical conduct by World Medical Association (72) through the cooperation between the government, represented mainly by the ministry of health affairs, and the private sectors, represented mainly by the respective professional associations (e.g. Indonesian Doctor Association - IDI, Pharmacy Expert Association - PAFI), to complement the existing state regulations regarding medical and health. These conducts and laws have always been infused to the national curriculum of medical and other health-related science, as an integral part of the effort to plant the best virtues into the next generations of medical workers in Indonesia (73). There are several key points that can be highlighted as the moral ground for the professional in these fields, namely respectful (respect the autonomy of patient), justice, professional, and honesty(74).

In construction industry, the current regulation has been said to attract the interest of young people to become part of construction sector, mainly due to the positive feel towards the law protection guarantee offered by the government through the law, as well as the decision to raise the monetary threshold of the construction project that can be coordinated by the private sector, which surely opens more opportunity for further development(75)(76). Another example is the growing opportunity to recruit fresh graduates into the management trainee programme, a special fast-track programme for the ones who would love to speed up their path into leadership/high management level. The construction sector is also highly exposed to the idea, where a lot of large-scale companies (ultimately the state-owned companies) has opened and tried to reach the fresh graduates to serve the purpose(77)(78)(79). In addition, there is a collaboration with academic institutions to instil the ethical values and Pancasila to the prospective engineers and professionals by means of several courses related to ethics and sustainable development as well as Pancasila(80). These actions are executed to produce future engineers that possess the integrity and ability to lead and hold responsibility according to a carefully-tailored plan, whose focus is mainly on fabricating a sustainable development in infrastructure projects $(81)(82)$. 
From all the explanations, it can be concluded that there is a promising trend regarding the endeavour to improve the quality of work in various sectors of industry based on the required ethical values virtues, which, in turn, sparks the interest of the younger generations to be involved in the respective sectors. Obviously, further developments need to be carried on by a strong leadership that possesses strong, positive virtues such as professionalism, honesty, visionary, empathy, and other characteristics mentioned previously to drive the whole developments in a sustainable direction that treats each aspects equally, to create long lasted services for human welfare.

\section{CONCLUSION}

Science can be defined as a journey to build comprehensive knowledge regarding natural and social worlds based on a systematic methodology. However, the more important aspect is to conclude the facts that have been obtained from the observation or experiments. The whole process described here indicates a pivotal role of the actors behind the attempt. Therefore, a strong moral virtue must become an integral part that attaches to the involved stakeholders to promote a better future through scientific and technological enhancement. A set of ethical boundaries can be developed by using a descriptive approach, which judges a behaviour between two extreme edges: true or false, and good or bad; or a normative approach, which rather aims to suggest whether an action should be done or not. There are three most popular concepts that underlie both ethical approaches. One theory focuses to the impact of an action (consequentialism), one stresses the view to the act itself to check its compliance to the governing norm (deontology/duty ethics), and another one underlines the significance of possessing the essential virtue. All approaches hence need to be combined to formulate a detailed ethical instruction for any stakeholders involved in the development of science and technology, which defines the responsibility of the professional in the form of backwardslooking perspective to mitigate and bear the accountability to any negative effects of an initiative, and the forward-looking initiative based on the active role based on a high enthusiasm to promote better human welfare. All the accounted definitions of ethics need to be incorporated to build a sustainable and innovative leadership equipped with certain qualities such as vision, confidence, integrity, and so on. Indonesia has actually adopted the specified moral virtues and qualities based on Pancasila, in the form of the basic constitution (UUD 1945). Nonetheless, there remain numerous occasions from various sectors, among which are the academic, construction and medical sectors, which do not capture the ideal pictures in the constitution. Several cases that are presented herein range from the attempt of spreading false profile, the manipulation of the national scientific grading system through the attempt of excessive self-citation and producing low-quality works published through a poor quality media that also incorporates the act of nepotism in the collegial system, all of which are performed to boost the performance to gain incentive and popularity significantly. Such actions are also triggered by the reality of $R \& D$ the sector in Indonesia, which is the lack of a reliable source of funding and qualified personnel to develop the field. On the construction sector, there are also several notable disasters that are allegedly caused by human error. For instance, the case of the giant sinkhole with the depth of 10 meters in Gubeng street in Surabaya, which occurred mainly due to the absence of a sufficient retaining wall to support the remaining soil structure that had been disturbed by the construction of underground parking lot in a hospital nearby it caused by the technical error made by the engineering party involved in the project, resulting in a huge cost necessary for technical reparation as well as potential economic loss to the local companies within the street following the ten-days isolation period. Another huge case is the mudflow in Sidoarjo, which was allegedly linked to the error in the drilling activity as the possible main cause. Moreover, the potential ethical violations made by the government are also implied in both instances, in the form of the lack 
of control during the planning and implementation stage, as well as when taking the decisions to mitigate both tragedies based on ambiguous considerations. Moreover, there are also several reports of scandals in medical, and pharmacy, fields, regarding the effort to manipulate the ingredient of a drug or giving deceptive labelling for it, as well as a monopoly in the distribution of medicines achieved mainly through the partnership between the distributor and hospitals or doctors, which potentially leads to inflation to the market price. Even in the pandemic situation in 2020, there are several questionable decisions and behaviours, such as the regulation of large-scale social distancing instead of total lockdown that surely needs further examinations regarding the ethical aspects, also regarding the transparency of information spread to the public. Fortunately, certain ethical conducts have also existed in each described sector in Indonesia that administer the ideal behaviour of the involved stakeholders in respective fields. Moreover, there have also been numerous apparent endeavours by the necessary stakeholders to revolutionize the respective industries. For instance, there are numerous research grants issued mainly by the government for the research projects (the bigger role of the private sector is surely desirable), as well as scholarship given by the government and the private sectors to the prospective students, whose budgets are gradually increasing each year. In the particular pandemic situation in 2020, there are also several special grants for the related researches funded through the government initiative as well as a joint project with other countries. Lastly, in the construction sector, there is evidence of a growing trend of youth involvement in the industry caused by two major reasons. Firstly, the development of regulations which open more project opportunities for the newcomers guaranteed by a more cooperative law system. Another factor is a major trend in management trainee programme to recruit fresh graduates. In summary, Indonesia has undergone lots of struggles to improve the current situation and learn from past mistakes to open a vast opportunity, particularly for the youth to be part in the development and become future leaders in respective fields, equipped with the strong ethical values incorporated in the form of explicit ethical conducts.

\section{REFERENCES}

[1] Butler-Adam J. No Title. 2015.

[2] Sciencecouncil.org. Available from: https://sciencecouncil.org/about-science/ourdefinition-of-science/. [accessed 25 July 2020]

[3] Cassimally KA. Define Science. Available from:https://www.nature.com/scitable/blog/labcoat-life/define_science/. 2011 [accessed 26 July 2020].

[4] Popova M. What Is Science? From Feynman to Sagan to Asimov to Curie, an Omnibus of Definitions. Available from: https://www.brainpickings.org/2012/04/06/what-isscience/\#: :text=Science is a way of,an elderly Albert Einstein observed\%3A\&text=Science is an inherent contradiction,applied to the natural world.2012 [accessed 26 July 2020].

[5] Olive L. HISTORY AND PHILOSOPHY OF SCIENCE AND TECHNOLOGY. Encycl Life Support Syst. III.

[6] Bentham J. Introduction to the Principles of Morals and Legislation. 2nd ed. 1823. Available from: https://www.laits.utexas.edu/poltheory/bentham/ipml/ipml.c01.html

[7] Schwartz B. Practical Wisdom: The Right Way to Do the Right Thing. Available from: https://www.psychologytoday.com/sg/blog/practical-wisdom/201012/practical-wisdomthe-right-way-do-the-right-thing, 2010 [accessed 30 July 2020]

[8] Jing S, Doorn N. Engineers' Moral Responsibility: A Confucian Perspective. Sci Eng Ethics. 26(2020), 233-53. Available from: https://doi.org/10.1007/s11948-019-00093-4

[9] Poel I van de, Royakkers L. Ethics, Technology and Engineering: An Introduction. 1st ed. 2011.

[10] Thompson DF. Moral responsibility and public officials. Am Polit Sci Rev. 74 
(1980),905-16.

[11] Doorn N, Nihlén Fahlquist J. Responsibility in Engineering: Toward a New Role for Engineering Ethicists. Bull Sci Technol Soc.30 (2010) 222-30.

[12] Durbin PT. Engineering professional ethics in a broader dimension. Interdiscip Sci Rev. 33 (2008), 226-33.

[13] Lynch WT, Kline R. Engineering practice and engineering ethics. Eng Ethics. 25 (2017), 601-32.

[14] Pritchard MS. Responsible Engineering: The Importance of Character and Imagination. Sci Eng Ethics. 7 (2001), 391-402.

[15] Harris CE. The good engineer: Giving virtue its due in engineering ethics. Sci Eng Ethics. 14 (2008), 153-64.

[16] Grigg NS, Criswell ME, Fontane DG, Siller TJ. ASCE Code of Ethics. Civ Eng Pract Twenty-First Century. (2001), 243-8.

[17] Anderson AR. Good Leaders Are Invaluable To A Company. Bad Leaders Will Destroy It. Available from: https://www.forbes.com/sites/amyanderson/2013/01/14/good-leadersare-invaluable-to-a-company-bad-leaders-will-destroy-it/\#124635091138, 2013 [accessed 18 July 2020].

[18] Muteswa, T., P. R. Qualities of a Good Leaders and the Benefits of Good Leadership to an Organization: A Conceptual Study. Eur J Bus Manag. 8 (2016), 136.

[19] Vojta M. Characteristics of the Effective Leader. Nurs Outlook. 21 (2010), 721-3. Available from: http://www.ncbi.nlm.nih.gov/pubmed/12189123

[20] Winston B, Patterson K. An integrative definition of leadership. Int J Leadersh Stud. 1 (2006), 6-66.

[21] (University of Cambridge Institute). Global Definitions of Leadership and Theories of Leadership Development: Literature Review. 2017. Available from: https://www.britishcouncil.org/sites/default/files/final_leadership_composite_report_with _references_26-06-17.pdf

[22] CNBC Indonesia. 7 Orang \& 13 MI Tersangka, Ada Korupsi Berjamaah Jiwasraya? Available from: https://www.cnbcindonesia.com/market/20200625214558-17-168166/7orang-13-mi-tersangka-ada-korupsi-berjamaah-jiwasraya, 2020 [accessed3 August 2020].

[23] CNN Indonesia. Terduga Korupsi Bansos Corona dari Wali Kota Hingga Ketua RT. Available from: https://www.cnnindonesia.com/nasional/20200730203801-12530862/terduga-korupsi-bansos-corona-dari-wali-kota-hingga-ketua-rt, 2020 [accessed 4 August 2020]

[24] Saputri M. Dwi Hartanto Meminta Maaf Soal Klaim Prestasi di Belanda. Available from: https://tirto.id/dwi-hartanto-meminta-maaf-soal-klaim-prestasi-di-belanda-cx4s, 2017 [accessed 28 July 2020].

[25] Ramadhani Y. Skandal Dwi Hartanto dan Pantangan Etis Para Peneliti. Available from: https://tirto.id/skandal-dwi-hartanto-dan-pantangan-etis-para-peneliti-cx5Y, 2017 [accessed 20 July 2020].

[26] KR dan T, Nasional BR dan I. Pemberitahuan Pengecekan Kualitas data di SINTA. Available from: https://www.ristekbrin.go.id/pengumuman/pemberitahuan-pengecekankualitas-data-di-sinta/, 2018 [accessed 4 August 2020].

[27] Chawla DS. Indonesia's scientists voice concerns about the country's researcher ranking system. Available from: https://cen.acs.org/policy/publishing/Indonesias-scientists-voiceconcerns-countrys/96/web/2018/12, 2018 [accessed 30 July 2020].

[28] Abraham J, Irawan DE, Dalimunthe S. Jalan evolusi bibliometrik Indonesia. Available from: https://theconversation.com/jalan-evolusi-bibliometrik-indonesia-104781， 2019 [accessed 25 July 2020].

[29] Saroh M. Dana Riset Indonesia Paling Rendah di Asia Tenggara. Available from: 
https://tirto.id/dana-riset-indonesia-paling-rendah-di-asia-tenggara-chUP, 2017 [accessed 25 July 2020].

[30] Gerintya S. Periksa Data: Kondisi Dunia Penelitian di Indonesia. Tirto.id. Available from: https://tirto.id/kondisi-dunia-penelitian-di-indonesia-cvvj, 2017 [accessed 25 July 2020].

[31] S LJ. Sri Mulyani Buka-bukaan Soal Anggaran Riset yang Cuma Rp 35 T. CNBC Indonesia. Available from: https://www.cnbcindonesia.com/news/20190731130600-488853/sri-mulyani-buka-bukaan-soal-anggaran-riset-yang-cuma-rp-35-t, 2019 [accessed 26 July 2020].

[32] Hariyanto I. Kajian KPK: Dana Penelitian di RI Sangat Rendah dan Tidak Terintegrasi. Detiknews. Available from: https://news.detik.com/berita/d-5055871/kajian-kpk-danapenelitian-di-ri-sangat-rendah-dan-tidak-terintegrasi, 2020 [accessed 21 July 2020].

[33] Rikin AS. Ini 5 Masalah yang Bikin Riset di Indonesia Mandek. Beritasatu. Available from: https://www.beritasatu.com/nasional/538708-ini-5-masalah-yang-bikin-riset-diindonesia-mandek, 2019 [accessed 22 July 2020].

[34] Lembaga Ilmu Pengetahuan Indonesia. Empat Masalah Penelitian Indonesia Versi LIPI. Available from: http://lipi.go.id/berita/single/Empat-Masalah-Penelitian-Indonesia-VersiLIPI/9408, 2014 [accessed 22 July 2020].

[35] Umaiyah S. Publikasi Hasil Penelitian di Indonesia Masih Rendah. Available from: https://jogja.tribunnews.com/2019/07/17/publikasi-hasil-penelitian-di-indonesia-masihrendah, 2019 [accessed 23 July 2020].

[36] Boediwardhana W. "I thought it was an earthquake": Giant sinkhole opens on busy Surabaya road. The Jakarta Post. Available from: https://www.thejakartapost.com/news/2018/12/19/i-thought-it-was-an-earthquake-giantsinkhole-opens-on-busy-surabaya-road.html, 2018 [accessed 18 July 2020].

[37] 6 L. Menilik Penyebab Jalan Raya Gubeng Ambles. Available from: https://www.liputan6.com/regional/read/3854840/menilik-penyebab-jalan-raya-gubengambles, 2018 [accessed 22 July 2020].

[38] Kompas Surabaya. 6 Tersangka Kasus Jalan Gubeng Surabaya Ambles Jalani Sidang Perdana. Available from: https://surabaya.kompas.com/read/2019/10/07/17412451/6tersangka-kasus-jalan-gubeng-surabaya-ambles-jalani-sidang-perdana, 2019 [accessed 20 July 2020].

[39] BBC Indonesia. Jalan raya Gubeng ambles, kontraktor abaikan aspek struktur tanah?. Available from: https://www.bbc.com/indonesia/indonesia-46622742, 2018 [accessed 22 July 2020].

[40] Mohsin A. The Sidoarjo Mudflow and the Muddiness of an Environmental Disaster. Available from: http://www.environmentandsociety.org/arcadia/sidoarjo-mudflow-andmuddiness-environmental-disaster, 2017 [accessed 23 July 2020].

[41] Akbar AA. Konspirasi di balik lumpur Lapindo: dari aktor hingga strategi kotor. 1st ed. Galangpress, editor. Yogyakarta: Galangpress; 2007. Available from: https://books.google.co.id/books?id=CTOsFoj_L7AC\&pg=PA85\&lpg=PA85\&dq=Kersa m+Sumanta\&source $=$ bl\&ots=McsbDJlWi\&sig=ACfU3U0G3D18qlYPy4KTtXcnbNrPk 8tYXA\&hl=id\&sa=X\&ved=2ahUKEwjTjoaJ9efiAhVDsY8KHRBqANIQ6AEwAXoEC $\mathrm{B} 0 \mathrm{QAQ} \# \mathrm{v}=$ onepage \&q\& $\mathrm{f}=$ false

[42] Tingay MRP, Rudolph ML, Manga M, Davies RJ, Wang C. Initiation of the Lusi mudflow disaster Diverting lava flows in the lab. 2015;8(July):7-8.

[43] Revianur A. Pakar: Lumpur Sidoarjo Murni Kesalahan Pengeboran. Kompas. Available from: https://nasional.kompas.com/read/2012/08/07/19093138/Pakar.Lumpur.Sidoarjo. Murni.Kesalahan.Pengeboran, 2012 [accessed 27 July 2020].

[44] Liputan 6. Geolog Dunia: Lumpur Lapindo Kesalahan Pengeboran. 2008.

[45] McVeigh T. Lusi volcano eruption blamed on mining firm by British-led science team. 
Available from: https://www.theguardian.com/world/2010/feb/14/lusi-volcano-scientistsblame-lapindo, 2010 [accessed 25 July 2020].

[46] Revianur A. Pakar: Lumpur Sidoarjo Murni Kesalahan Pengeboran. Available from: https://nasional.kompas.com/read/2012/08/07/19093138/Pakar.Lumpur.Sidoarjo.Murni.

Kesalahan.Pengeboran, 2012 [accessed 26 July 2020].

[47] Strait Times. Indonesia should not forget Lapindo mudflow disaster: The Jakarta Post. Available from: https://www.straitstimes.com/asia/se-asia/indonesia-should-not-forgetlapindo-mudflow-disaster-the-jakarta-post, 2016 [accessed 27 July 2020].

[48] Hermawan S, Sidoarjo UM. PRAKTIK KOTOR BISNIS INDUSTRI FARMASI DALAM BINGKAI INTELLECTUAL CAPITAL DAN TELEOLOGY THEORY. J Akunt Multiparadigma. 4 (2013) 40-54.

[49] Pujiastoeti S, Imaniyati NS, Suminar SR. Kerjasama Pemasaran Obat Antara Dokter dengan Pedagang Besar Farmasi di Kota Bandung Dihubungkan Dengan Kode Etik Kedokteran dan KepMenKes No. 3987/A/K/1973. 2004;

[50] Tribun Rakyat. Diduga Monopoli Obat, Kimia Farma Diduga Rugikan Negara Rp97 Miliar. Available from: https://tribunrakyat.com/14108/28/11/2019/diduga-monopoliobat-kimia-farma-diduga-rugikan-negara-rp97-miliar.html, 2019 [accessed 28 July 2020].

[51] Raja Oloan Tumanggor. Problematika Etis dalam Penanganan Virus Corona Covid-19. Kompas.com.Available from: https://www.kompas.com/sains/read/2020/04/28/ 193000623/problematika-etis-dalam-penanganan-virus-corona-covid-19?page=all, 2020 [accessed 30 July 2020].

[52] Sushmita CI. Buruknya Etika Berkomunikasi Di Tengah Krisis Covid-19. Solo Pos. Available from: https://www.solopos.com/buruknya-etika-berkomunikasi-di-tengahkrisis-covid-19-1067166, 2020 [accessed 1 August 2020].

[53] Peraturan Kepala Lembaga Ilmu Pengetahuan Indonesia Nomor 06/E/2013, Lembaga Ilmu Pengetahuan Indonesia, Indonesia, 2014.

[54] Kode Etik dan Kode Perilaku Pegawai Kementerian Pekerjaan Umum dan Perumahan Rakyat, Kementerian Pekerjaan Umum dan Perumahan Rakyat, Indonesia, 2017.

[55] UU no.2. Undang-Undang Republik Indonesia No 2 TAHUN 2017 Tentang Jasa Konstruksi, Indonesia, 2017.

[56] Panduan Penelitian dan Pengabdian Kepada Masyarakat Edisi XII, Direktorat Riset dan Pengabdian Masyarakat Dikti, 2018.

[57] Jannah SM. Pandemi COVID-19: Mengapa Anggaran Kemenristek Dipangkas hingga Rp40 Triliun? Tirto.id. Available from: https://tirto.id/mengapa-anggaran-kemenristekdipangkas-hingga-rp40-triliun-eL73, 2020 [accessed 30 July 2020].

[58] Kementerian Keuangan. Anggaran Penelitian Dalam APBN 2019 Rp35,7 Triliun, Rp99 Miliar Masuk Dana Abadi Penelitian. Available from: https://www.kemenkeu.go.id/publikasi/berita/anggaran-penelitian-dalam-apbn-2019rp35-7-triliun-rp99-miliar-masuk-dana-abadi-penelitian/, 2019 [accessed 1 August 2020].

[59] LPDP. Lembaga Pengelola Dana Pendidikan. Available from: https://www.lpdp.kemenkeu.go.id/, 2020 [accessed 27 July 2020].

[60] Tokopedia. Tokopedia Scholarship. Available from: https://www.tokopedia.com/ scholarship/, 2020 [accessed 28 July 2020].

[61] Bank Central Asia. Beasiswa BCA. Available from: https://karir.bca.co.id/peluangkarir/cari-lowongan/?pos=Program Beasiswa, 2020 [accessed 28 July 2020].

[62] Djarum Foundation. Djarum Beasiswa Plus. Available from: https://djarumbeasiswaplus.org/, 2020 [accessed 28 July 2020].

[63] CNN Indonesia. Menristek Ungkap Ironi Peran Swasta dan Mandeknya Riset di RI. Available from: https://www.cnnindonesia.com/teknologi/20191219131355-185458343/menristek-ungkap-ironi-peran-swasta-dan-mandeknya-riset-di-ri, 2019 [accessed 
1 August 2020].

[64] Antoni A. Tumbuhkan Minat Riset Generasi Muda, Indofood Beri Dana Penelitian. Available from: https://ekbis.sindonews.com/berita/1395048/34/tumbuhkan-minat-risetgenerasi-muda-indofood-beri-dana-penelitian, 2019 [accessed 3 August 2020].

[65] Tim Publikasi Katadata. Pengembangan Riset, Menanti Penguatan Peran Swasta. Available from: https://katadata.co.id/timpublikasikatadata/infografik/5e9a5039e618b/ pengembangan-riset-menanti-penguatan-peran-swasta, 2019 [accessed 3 August 2020].

[66] Rencana Induk Riset Nasional tahun 2017-2045, Kementerian Riset dan Teknologi Republik Indonesia, 2017.

[67] Ari Supriyanti Rikin. Dana Riset Masih Didominasi Pemerintah. Beritasatu. Available from: $\quad$ https://www.beritasatu.com/nasional/538706-dana-riset-masih-didominasipemerintah, 2019 [accessed 28 July 2020].

[68] Mutiara P. Minat Peneliti Remaja Meningkat. Media Indonesia. Available from: https://mediaindonesia.com/read/detail/50890-minat-peneliti-remaja-meningkat, 2016 [accessed 27 July 2020].

[69] Harususilo YE. Menjawab Tantangan Minimnya Minat Menjadi Peneliti di Indonesia. Kompas.com. Available from: https://edukasi.kompas.com/read/2018/11/22/16091231/ menjawab-tantangan-minimnya-minat-menjadi-peneliti-di-indonesia?page=all, 2018 [accessed 27 July 2020].

[70] Ayu W. 24 Proposal Riset COVID-19 UI Terima Pendanaan Kemenristek/BRIN Sebesar 8,1 Milyar. Universitas Indonesia. Available from: https://www.ui.ac.id/24-proposalriset-covid-19-ui-terima-pendanaan-kemenristek-brin-sebesar-81-milyar/, 2020 [accessed 20 July 2020].

[71] Indonesia C. Riset Covid, Kemenristek dan Inggris Guyur Puluhan Miliar. Available from: https://www.cnnindonesia.com/teknologi/20200428075558-199-497908/risetcovid-kemenristek-dan-inggris-guyur-puluhan-miliar, 2020 [accessed 19 July 2020].

[72] Panduan Etika Medis Disertai Studi Kasus-kasus Etika Pelayanan Medis Sehari-Hari, Pusat Studi Kedokteran Islam, Fakultas Kedokteran UMY, 2004.

[73] Standar Kompetensi Dokter Indonesia, Konsil Kedokteran Indonesia, 2012.

[74] Etika Profesi dan Hukum Kesehatan, Kementerian Kesehatan Republik Indonesia, 2017.

[75] Lembaga Pengelola Jasa Konstruksi. UU Jaskon Baru Perkuat Perlindungan Hukum bagi Pelaku Usaha. Available from: https://lpjk.net/uu-jaskon-baru-perkuat-perlindunganhukum-bagi-pelaku-usaha-2/, 2017 [accessed 4 August 2020].

[76] Anam C. Minat Generasi Milenial Ke Jasa Konstruksi di Malang Terus Tumbuh. Available from: https://surabaya.bisnis.com/read/20190115/532/878963/minat-generasimilenial-ke-jasa-konstruksi-di-malang-terus-tumbuh, 2019 [accessed 131 July 2020].

[77] WIKA Gedung. Wika Gedung. Available from: https://www.wikagedung.co.id/dev/karir_/berkarir_bersama_kami.html, 2020 [accessed 4 August 2020].

[78] Ikatan Alumni Universitas Negeri Malang. Management Trainee Program of Mechanical Electrical PT. Pembangunan Perumahan (Persero) Tbk. Available from: http://ika.um.ac.id/management-trainee-program-of-mechanical-electrical-ptpembangunan-perumahan-persero-tbk/, 2019 [accessed 19 July 2020].

[79] PT. Waskita Karya (Persero) Tbk. Career Opportunities Waskita Karya. Available from: https://www.waskita.co.id/pages/humancapitals/careeropportunities?lang=en, 2020 [accessed 1 August 2020].

[80] Spada Indonesia - Kementerian Pendidikan dan Kebudayaan. Pendidikan Pancasila. Available from: https://spada.kemdikbud.go.id/course/pendidikan-pancasila, 2020 [accessed 1 August 2020].

[81] Standar Nasional Pendidikan Tinggi Permendikbud No. 3/2020, Kementerian Pendidikan dan Kebudayaan RI, 2020. 
[82] Warta Ekonomi. Apa Peran Perguruan Tinggi dalam Mencapai SDGs? Ini Jawaban Menteri PPN. Available from: https://www.wartaekonomi.co.id/read215420/apa-peranperguruan-tinggi-dalam-mencapai-sdgs-ini-jawaban-menteri-ppn, 2019 [accessed 2 August 2020]. 